\title{
MENGAPA SULIT MEMBEDAKAN PERMUTASI DAN KOMBINASI
}

\author{
Mahyudi \\ Program Studi Pendidikan Matematika FKIP Universitas Muhammadiyah Bengkulu \\ didimahyudi21@gmail.com
}

\begin{abstract}
ABSTRAK
Kesulitan dalam belajar merupakan masalah umum yang khas dalam suatu proses pembelajaran. Kurangnya pemahaman konsep menjadi kendala utama keberhasilan seorang mahasiswa dalam menyelesaikan suatu permasalahan matematika. Salah satunya adalah kesulitan dalam membedakan permutasi dan kombinasi. Karakteristik masalah yang bersifat terbuka dan membutuhkan kemampuan penalaran yang baik, juga membuat mahasiswa mengalami kegagalan dalam menguasai materi ini. Dalam mengatasi masalah ini, diperlukan suatu analisis yang baik dan gambaran yang menyeluruh, sehingga dapat memberikan solusi yang tepat. Analisis yang dapat memberikan suatu tinjauan untuk masalah yang berbentuk soal cerita seperti dalam kasus permutasi dan kombinasi ini adalah analisis Newman. Analisis ini dimulai dari tahap membaca, memahami, mentransformasi, memproses masalah sampai menulis jawaban akhir. Hasil penelitian yang diperoleh dari lembar tes dan wawancara menunjukkan bahwa kendala utama mahasiswa dalam menyelesaikan permasalahan permutasi dan kombinasi adalah kurangnya kemampuan memahami masalah dan masih lemahnya kemampuan penalaran dalam soal cerita.
\end{abstract}

Kata kunci:permutasi, kombinasi, analisis Newman

\begin{abstract}
Difficulty in learning is already a common problem that is typical in a learning process. Lack of understanding of the concept of an obstacle to the success of a student in solving a mathematical problem. One is the difficulty in distinguishing permutations and combinations. Characteristics of issues that are open and require good reasoning ability, also makes students fail to master this material. In addressing this issue, we need a good analysis and the whole description, so that it can provide the right solution. The analysis can provide an overview of the problem in the form of word problems as in the case of permutation and combination is the analysis Newman. This analysis started from the stage to read, understand, transform, process problems to write the final answer. The results of research obtained from the test sheets and interviews showed that the main obstacle in solving the problems of students permutation and combination is the lack of ability to understand the problems and weak reasoning abilities in terms of story.
\end{abstract}

Keyword: permutation, combination, Newman analysis

\section{Pendahuluan}

Pada saat ini, salah satu yang menjadi masalah utama dalam dunia pendidikan Indonesia adalah rendahnya mutu hasil pembelajaran. Masalah ini tidak hanya terjadi pada tingkat dasar dan menengah, akan tetapi juga dialami pada tingkat perguruan tinggi. Hal ini terutama terjadi pada bidang-bidang ilmu pasti termasuk matematika.

$$
\text { Pada umumnya kemampuan }
$$

akademik mahasiswa matematika masih 
sangat terbatas.Kekurangan yang sangat menonjol yaitu dalam hal kualitas mahasiswa yang menjadi input. Sebagian memang berasal dari SMA jurusan Ilmuilmu Alam, tetapi tidak sedikit yang berasal dari jurusan non eksakta bahkan dari sekolah-sekolah kejuruan yang notabene sangat jauh dari latar belakang matematika, seperti tata boga, kecantikan dan tata busana.

Akan tetapi, permasalahan dalam proses dan hasil belajar ini dialami hampir semua mahasiswa matematika tanpa tekecuali. Jurusan yang ditempuh pada saat di bangku SLTA memang bukan menjadi faktor utama. Akan tetapi karakteristik matematika yang hierarki, membuat cara belajar matematika, tidak hanya cukup didapatkan pada saat menerima suatu mata kuliah tertentu. Diperlukan pengetahuan dasar terlebih dahulu, terutama pemahaman konsep terhadap suatu materi untuk dapat memahami materi berikutnya.

Seperti yang diungkapkan Dahar (1988:95)bahwa “jika diibaratkan, konsep-konsep merupakan batu-batu pembangunan dalam berpikir." Artinya bahwa untuk menuju ke proses pembelajaran dengan materi yang lebih tinggi diperlukan kemampuan pemahaman konsep yang sangat mendalam dan memadai.

Sebagai contoh pada mata kuliah teori peluang yang diperoleh mahasiswa matematika pada semester 2.
Kemampuan matematika dasar seperti bilangan faktorial dan himpunan serta kemampuan logika dan penalaran sangat dituntut untuk dapat memahami mata kuliah ini. Ketiga komponen tersebut harus saling berkesinambungan satu sama lain. Kemampuan komputasi saja tidak cukup untuk dapat memahami materimateri pada teori peluang, terutama pada materi permutasi dan kombinasi.

Pada bagian ini, mahasiswa harus dapat menganalisis permasalahan terlebih dahulu sebelum mencari solusinya, karena kasus yang dihadapi pada materi ini pada umumnya dalam bentuk soalsoal cerita. Sebagian besar mahasiswa mengalami kesulitan dalam menyelesaikan soal cerita dalam bentuk soal penalaran. Hal ini dikarenakan kurangnya keterampilan dalam menterjemahkan kalimat sehari-hari ke dalam kalimat matematika. Barbu (2010: 7) mengatakan bahwa kompleksitas bahasa memiliki pengaruh signifikan terhadap persepsi mahasiswa tentang kesalahan dalam menyelesaikan soal cerita yang terkait dengan pemahaman teks.

Oleh karena itu, penyajian soal cerita merupakan hal yang perlu diperhatikan.Kesalahan lain juga terjadi pada saat menentukan metode yang digunakan. Mahasiswa sering kali tidak dapat membedakan kapan penggunaan metode permutasi dan kapan penggunaan kombinasi. Sebagai contoh pada 
permasalahan berikut ini "Suatu tim debat terdiri atas 3 anak laki-laki dan 3 anak perempuan. Tentukanlah jumlah cara mereka dapat duduk dalam suatu baris di mana anak laki-laki dan perempuan masing-masing harus duduk bersanding."

Kasus seperti ini termasuk dalam masalah terbuka, artinya banyak metode atau cara yang dapat digunakan untuk memecahkan masalah tersebut. Akan tetapi, hampir sebagian besar mahasiswa kurang berusaha keras untuk dapat memahami soal cerita seperti ini karena kemampuan penalaran yang masih kurang. Padahal yang menjadi langkah awal dalam memecahkan suatu permasalahan matematika adalah memahami soal. Tahap selanjutnya adalah membedakan masalah tersebut termasuk permutasi atau kombinasi. Kesulitan-kesulitan seperti ini berdampak pada rendahnya hasil belajar mahasiswa.

Dalam mengatasi kesulitan belajar, tidak hanya menjadi tugas seorang pengajar. Akan tetapi perlu kerjasama yang baik antara dosen dan mahasiswa dalam mencari solusi untuk mengatasi hal tersebut. Analisis ini dapat menjadi langkah awal dalam melakukan perbaikan proses belajar mengajar yang nantinya akan berimbas pada meningkatnya pemahaman dan hasil belajar mahasiswa.

\section{TahapanAnalisisKesalahanNewman}

Metode analisis kesalahan
Newman diperkenalkan pertama kali pada tahun 1977 oleh Anne Newman, seoranggurubidangstudimatematikadi

Australia.Dalam

metodeini,disarankanlimakegiatanyangsp esifik sebagai suatu yang sangat krusial untuk membantu menemukan letak kesalahanyangterjadipadapekerjaan siswaketikamenyelesaikansuatu masalah berbentuk soal cerita. Siswadimintamengerjakanlima kegiatan berikut sewaktu mengerjakan permasalahan tersebut, (Clements:1998).

1. Silahkanbacakanpertanyaantersebut. Jikakamutidakmengetahui suatu kata tinggalkan saja.

2. Katakan apa pertanyaan yangdimintauntuk kamu kerjakan

3. Katakan bagaimana kamu akan menemukan jawabannya.

4. Tunjukkanapayangakankamukerjaka nuntukmemperolehjawaban tersebut. Katakan dengan keras sehingga dapat dimengerti bagaimana kamu berfikir.

5. Tuliskan jawaban dari pertanyaan tersebut.

Kelima kegiatan ini dapat digunakan untuk menemukan dimana dan kenapa siswa melakukan kesalahankesalahan terhadap masalah matematikasoalcerita.AnneNewmansela njutnyamengemukakanbahwasetiap siswa yang ingin menyelesaikanmasalahmatematikasoalce rita,harus bekerja melalui lima tahapan 
berikut, yaitu (1) membaca masalah (reading),(2)memahamimasalah(compre hension),

transformasimasalah(transformation),

(4) keterampilan proses (process skill),(5)penulisan jawaban (encoding).

ParakitipongdanNakamura

(2006)membagi

limatahapananalisiskesalahan Newman menjadi dua kelompok kendala yang dialami siswa dalammenyelesaikan masalah. Kendala pertama adalah masalah dalamkelancaran linguistik dan pemahamankonseptualyangsesuaidengan tingkat membaca sederhana dan memahami makna masalah. Kendala ini dikaitkandengantahapanmembaca (reading)danmemahami (comprehension) maknasuatupermasalahan.Sedangkan kendalakeduaadalah masalahdalam pengolahanmatematikayangterdiridari transformasi (transformation), keterampilan proses (process skill), dan penulisanjawaban (encoding).

Beberapapenelitianyangberkaitan denganpenerapanmetodeanalisis kesalahan Newman pada pembelajaran matematika telah banyak dilakukan.Clement (1980)dalam penelitiannyamenyimpulkanbahwakesala han terbanyakyangdilakukansiswadalam menyelesaikansoalceritaadalah pada tahap pemahaman makna suatu permasalahan(comprehension), transformasi(transformation),keterampil anproses(prosessskill), dan kecerobohan
(carelessness).White

(2005)melaporkanbahwapenerapan

metode analisis kesalahan Newman dalam kelas dapat mengaktifkan siswa,menemukankesalahanyangdilakuk anolehsiswadankemudianmelakukansesu atuuntukmembantunya.

Penelitian yang dilakukan di Indonesia pun sudah banyak yang membahas tentang masalah ini terutama di sekolah-sekolah menengah baik SMP, SMA maupun SMK. Salah satunya penelitian Satoto (2013) di Keals X SMAN 1 Kendal yang mendapatkan bahwa kesalahan yang paling banyak dilakukan siswa adalah kesalahan memahami masalah karena salah dalam membuat ilustrasi.

Selain itu, penelitian yang dilakukan di kelas XI IPA SMA Muhammadiyah Meulaboh Johan Pahlawan oleh Jamal (2014) menyimpulkan bahwa adanya kesulitan belajar pada materi peluang dikarenakan kurangnya pemahaman konsep siswa. Selain itu juga disebabkan karena siswa kurang memiliki keinginan untuk menyelesaikan soal terutama dalam bentuk soal cerita.

\section{Metode Penelitian}

Penelitian ini menggunakan pendekatan kualitatif dengan subjek penelitian mahasiswa Program Studi Pendidikan Matematika FKIP Universitas Muhammadiyah Bengkulu Tahun 2014. Penggambaran kesulitan yang dialami 
mahasiswa

dilakukan

dengan

menggunakan analisis kesalahan

Newman berdasarkan hasil tes dan wawancara terbuka.

Analisis kesalahan pada penelitian ini dikelompokkanmenjadi lima kategori yaitu:

\section{Kesalahan membaca soal}

Indikator kesalahan membaca soal adalah tidak bisa membaca soal yang telah diberikan, tidak bisa menemukan kata-kata atau informasi penting dalam soal,sehingga tidak bisa mengerjakan soal yang telah diberikan.

\section{Kesalahan memahami soal}

Kesalahan memahami soal terjadi apabilamahasiswa tidak dapat menentukan hal-hal apa saja yang diketahui dan ditanyakandalam soalatausebenarnyasudahdapatmemahami soal, tetapi belum menangkap informasi yang terkandung dalam pertanyaan, sehingga

tidakdapatmemproseslebihlanjutsolusi dari permasalahan.

\section{Kesalahan transformasi soal}

Mahasiswa telah memahami apa yang diminta soal untuk diselesaikan,tetapi gagal dalam memahami soal untuk diubah ke dalam kalimat matematika yang benar atau pemodelan matematikanya. Siswa tidak dapatmengidentifikasi operasiataumetode yang diperlukan untuk menyelesaikan soal tersebut. Termasuk dalam hal ini adalah kesalahan dalam menentukan metode yang digunakan, permutasi atau kombinasi.

\section{Kesalahan keterampilan proses}

Mahasiswa sudah dapat mengidentifikasi

operasiataumetodeyangsesuai, tetapi tidak mengetahui prosedur yang dibutuhkan untuk meneruskan operasi tersebut. Sehingga tidak dapat melanjutkan perhitungan atau komputasinya tersebut. Termasuk juga tidak menuliskan tahapan perhitungan dengan benar.

5. Kesalahan menuliskan jawaban akhir

Mahasiswa sudah dapat mengerjakan penyelesaian secara tepat, tetapi

tidakdapatmengekspresikanpenyelesaiant ersebutkedalam kalimat matematika yang dapat diterima atau sesuai dengan konteks soal.

\section{Hasil dan Pembahasan}

Hasil penelitian diperoleh setelah memberikan lima soal tentang permutasi dan kombinasi. Secara keseluruhan nilai rata-rata yang diperoleh mahasiswa untuk kelima soal tersebut adalah 57,48 . Hasil ini masih sangat jauh dari standar yang diharapkan. Selanjutnya akan dilihat jawaban mahasiswa berdasarkan kelima tahapan analisis Newman.

\section{Tahap Membaca Masalah (Reading)}

Beberapa soal yang diberikan memiliki tipe yang sama dengan soal-soal 
yang sudah dipelajari sebelumnya, sehingga mahasiswa tidak mengalami kesulitan dalam membaca soal.Selain karena soal dibuat dalam bahasa Indonesia, kata-kata yang digunakan juga tidak menggunakan istilah asing.

Meskipun demikian masih ada beberapa mahasiswa yang mengalami kebingungan dalam mencari informasi utama misalnya pada soal berikut "Dalam huruf abjad bahasa Inggris terdapat 26 huruf yang terdiri atas 21 huruf konsonan dan 5 huruf vokal. Tentukan banyaknya kata (tidak perlu memiliki arti) dengan lima huruf yang dapat disusun yang memuat 3 huruf konsonan dan 2 huruf vocal berbeda, jika (i) Kata-katanya harus berawalan huruf $F$ dan berakhiran $T$ (ii) Kata-katanya harus memuat huruf E, F dan G."

Kesalahan dalam memaknai kalimat pada soal tersebut dengan adanya instruksi dari beberapa urutan pengerjaan yang membuat mahasiswa kesulitan menemukan kata kunci untuk menyelesaikan permasalahan tersebut.

\section{Tahap}

\section{MemahamiMasalah(Comprehension)}

Secara keseluruhan soal, sebanyak $64,45 \%$ mahasiswa tidak memahami soal dengan baik. Pada soal nomor 1 berikut "Suatu kelas terdiri atas 9 pria dan 3 wanita. Tentukanlah jumlah cara seorang pengajar dapat memilih suatu komisi beranggotakan 4 orang dari kelas tersebut, jika: (i) hanya ada satu wanita (ii) paling tidak satu wanita. Kurangnya kemampuan penalaran dalam memahami soal tersebut membuat mahasiswa banyak melakukan kesalahan, bahkan ada yang tidak menjawab.

Beberapa kesalahan pemahaman pada soal ini antara lain: memahami bahwa yang dipilih adalah 1 dari 3 orang wanita yang ada. Pada soal bagian (ii) ada yang memahami bahwa yang dipilih semuanya wanita. Kesalahan yang sangat fatal adalah beberapa mahasiswa salah dalam memilih metode, karena kurangnya pemahaman pada soal tersebut.

Pada soal ke-2 yang berbunyi "Dalam berapa banyak carakah 3 orang pria dan 3 orang wanita dapat duduk pada sebuah meja bundar, jika: (i) dua wanita tertentu tidak boleh duduk berdampingan, (ii) tiap wanita harus diapit oleh dua orang pria."

Pemahaman mahasiswa terhadap soal tersebut bervariasi. Ada yang beranggapan bahwa apabila 2 wanita tidak boleh duduk berdampingan, maka sisa anggota ada 4 orang dan menjawab dengan 4! cara. Pemahaman lainnya adalah 3 ! untuk pria, 2! untuk wanita tertentu dan dianggap 1 orang, sehingga jawabannya adalah 3 !1! cara. Selain itu ada juga yang menjawab dengan banyaknya susunan keseluruhan dikurangkan dengan susunan wanita yang tidak boleh duduk bersama. Padahal pada prinsip sebenarnya dikurangkan dengan 
banyak susunan 2 orang wanita dapat duduk bersama.

Sedangkan pada soal bagian kedua menganggap bahwa dengan mengambil 2 wanita dan 2 pria sehingga jawabannya adalah 2!x2! cara. Selain pemahaman ini, ada yang memahami bahwa tetap ada 6 orang dengan menghitung 3 !x 3 ! cara. Ada juga yang menjawab dengan benar. Akan tetapi dengan pemahaman bahwa 2 orang dikeluarkan terlebih dahulu sehingga ada 2! susunan. Sedangkan 4 orang sisanya karena harus berdampingan maka ada sebanyak (4-1)! = 3!. Jadi secara keseluruhan ada 2 ! 3 ! = 12 susunan.

Ada juga mahasiswa yang melakukan analisis sebagai berikut. Dari tiga orang pria dan tiga orang wanita masing-masing dianggap menjadi satu sehingga $n=2$. Secara keseluruhan ada sebanyak 2. 3 ! 3 ! = 36 susunan.

Pada soal berikutnya yang berbunyi "Ada 12 mahasiswa yang memenuhi syarat untuk menghadiri pertemuan tahunan perkumpulan mahasiswa nasional. Tentukan banyaknya cara untuk memilih 4 orang dari 12 mahasiswa tersebut, jika: (i) dua di antara mahasiswa terpilih merupakan pasangan menikah dan tidak akan hadir sendiri-sendiri (ii) dua di antara mahasiswa tersebut sedang bertengkar dan tidak akan hadir bersamaan."

Pada bagian pertama, ada yang beranggapan bahwa keduanya tidak terpilih, sehingga ada 10 rang yang tersisa dan akan diambil 4 orang. Sehingga ada $10 C 4=210$ cara. Ada juga yang menganalisis bahwa yang dimaksud adalah bahwa 1 orang harus hadir. Selanjutnya memilih 3 orang lagi dari 10 orang yang ada. Sehingga ada 10C3 = 120 susunan.

Pada soal bagian kedua banyak yang tidak memahami soal sama sekali sehingga tidak menjawab. Pada saat dilakukan wawancara sebagian menjawab karena bingung dalam menentukan kasus permutasi atau kombinasi. Ada salah satu pemahaman mahasiswa yang menganalisis soal bagian ini bahwa kalau tidak hadir bersamaan, maka ada sebanyak 2x 9C4 = 126 susunan.

Soal berikutnya adalah penggabungan antara konsep permutasi dan kombinasi dengan soal berikut "Dalam huruf abjad bahasa Inggris terdapat 26 huruf yang terdiri atas 21 huruf konsonan dan 5 huruf vokal. Tentukan banyaknya kata (tidak perlu memiliki arti) dengan lima huruf yang dapat disusun yang memuat 3 huruf konsonan dan 2 huruf vocal berbeda, jika (i) Kata-katanya harus berawalan huruf $F$ dan berakhiran $T$ (ii) Kata-katanya harus memuat huruf $E, F$ dan G."

Soal ini memiliki tingkat kesalahan pemahaman paling tinggi. Seperti pada penjelasan sebelumnya bahwa ketidakpahaman mahasiswa akan informasi utama pada soal tersebut 
akhirnya berimbas pada pemahaman soal ini dan menyebabkan banyak mahasiswa yang tidak menjawab.

Sebanyak $95 \%$ mahasiswa menjawab dengan permutasi karena beranggapan bahwa susunan huruf merupakan permutasi yang harus memperhatikan urutan. Padahal yang harus dilakukan menentukan kombinasi dari huruf-huruf yang tersisa, kemudian membuat susunan huruf yang diperoleh. Beberapa orang yang sudah melakukan analisis dengan benar yang memahami bahwa langkah pertama adalah menentukan kombinasi. Akan tetapi tidak memahami bahwa kemudian harus disusun sesuai dengan aturan permutasi.

Soal terakhir adalah "Dalam berapa cara angka-angka 0,1,2,3,4,5,6,7,8,9 dapat disusun sehingga: ( $i$ ) angka 0 dan 1 bersebelahan (ii) angka 0 dan 1 bersebelahan dan dalam bentuk 01."

Pemahaman tentang soal ini pun sangat beragam. Ada yang memahami bahwa ada 9 cara menyusunnya dengan sisa delapan tempat karena angka 0 dan 1 sudah menempati dua tempat. Sehingga dijawab dengan $9 \times 10 \mathrm{P} 8$ susunan. Pemahaman yang hampir sama juga menganalisis bahwa angka 0 dan 1 yang bersebelahan menjadi 1, sehingga tersisa 9 angka. Jawaban yang diberikan adalah $9 ! / 2$ ! susunan.

Pemahaman lainnya adalah bahwa dari 10 tempat yang tersedia, angka 0 dan
1 bersebelahan ada 18 kemungkinan. Dua tempat untuk angka 0 dan 1 dan delapan tempat untuk sisa delapan angka lainnya. Sehingga seluruhnya ada 18 x $2 \mathrm{P} 2 \times 8 \mathrm{P} 8$ susunan.

\section{Tahap}

\section{TransformasiMasalah(Transformation)}

Selain kesulitan dalam memahami masalah, kesalahan yang juga banyak dilakukan mahasiswa adalah dalam memilih prosedur penyelesaian antara permutasi dan kombinasi. Kesalahan paling banyak adalah pada soal ke-4 tentang kombinasi 26 huruf abjad.

Kesalahan pemahaman mahasiswa tentang soal ini adalah bahwa susunan huruf merupakan suatu kasus permutasi. Hal ini salah satunya dikarenakan banyak soal yang memiliki tipe sejenis yang merupakan permutasi.

Selain kurangnya pemahaman soal secara menyeluruh, faktor ketidaktelitian mahasiswa juga menjadi penyebab kesalahan dalam mentransformasi jawaban dengan benar.Ada juga kesalahan yang dilakukan yaitu tidak bisa menjelaskan prosedur-prosedur yang digunakan untuk menjawab soal tersebut, sehingga langsung membuat hasilnya.

\section{Tahap Keterampilan Proses (Process skill)}

Pada tahap ini, kesalahan yang banyak dilakukan berawal dari kurangnya pemahaman soal. Tetapi 
bukan kesalahan prosedur matematikanya.Sebagai contoh masih ada mahasiswa yang menuliskan aturan permutasi dengan rumus kombinasi, begitu juga sebaliknya.

Proses penghitungan yang tidak terlalu rumit, dapat mengurangi tingkat kesalahan operasi yang dilakukan mahasiswa. Walaupun masih ada yang melakukan kesalahan perhitungan faktorial.

Untuk soal ke-5, ada juga mahasiswa yang menyelesaikan dengan metode filling slot(pengisian tempat yang tersedia). Akan tetapi eksekusi akhir yang dilakukan masih terdapat kesalahan. Misalnya membuat seluruh kemungkinan yang ada sehingga memerlukan banyak slot. Selain itu, persoalan tentang susunan angka juga membuat mahasiswa bingung antara angka yang tersedia dengan banyaknya kemungkinan yang terjadi.

\section{Tahap Penulisan Jawaban (Encoding)}

Tahap analisis terakhir dari Newman adalah dalam menuliskan jawaban akhir. Hal yang sudah menjadi kebiasaan dalam penyelesaian soal matematika adalah tidak menuliskan hasil akhir atau kesimpulan jawaban. Mahasiswa yang sudah menjawab dengan benar, terkadang juga melupakan bahwa diperlukan representasi informasi dari apa yang ditanyakan soal.

Penyelesaian soal yang melalui beberapa tahapan menjadi salah satu penyebab kesalahan ini. Seperti pada soal nomor 6 misalnya. Setelah dapat menentukan banyaknya susunan masingmasing kemungkinan, mahasiswa tidak menuliskan hasil akhir secara keseluruhan.

Begitupun juga pada soal ke-3, langkah pertama dapat diselesaikan dengan mengambil pemisalan untuk keduanya hadir dan keduanya tidak dapat hadir. Akan tetapi, mahasiswa tidak menuliskan jawaban akhir yang semestinya harus dijumlahkan.

Berdasarkan analisis jawaban mahasiswa diperoleh bahwa kesulitan yang paling banyak dialami mahasiswa adalah dalam memahami soal. Hal ini karena mahasiswa tidak terlatih untuk menyelesaikan soal-soal yang membutuhkan penalaran. Soal-soal perhitungan lebih banyak dikuasai daripada soal-soal tentang penalaran terutama pada soal cerita. Hasil serupa juga diperoleh dari penelitian Junaedi (2012) tentang tipe kesalahan mahasiswa dalam menyelesaikan soal-soal geometri analitik berdasarkan Newman's Error Analysis (NEA) yang menyimpulkan bahwa Kesalahanyang paling panyak dilakukan mahasiswadalam mengerjakan soal pembuktian adalah pada tahap Comprehension dan Encoding.

Selain itu, penelitian yang dilakukan Mutakin (2013) pada mahasiswa Teknik Informatika di Universitas Indraparasta Jakarta pada 
mata kuliah Kalkulus I didapatkan bahwa kesulitan yang paling banyak dialami mahasiswa adalah kurangnya pengetahuan dasar dan pemahaman kalkulus seperti operasi fungsi dan pecahan.

Penelitian Shodiqin (2011) memberikan hasil yang tidak jauh berbeda. Kesulitan yang paling banyak dialami mahasiswa Pendidikan Matematika pada mata kuliah Geometri Transformasi adalah kurangnya pemahaman konsep.

Pemilihan metode dalam menyelesaikan masalah permutasi dan kombinasi juga menjadi kendala utama mahasiswa untuk mendapatkan jawaban akhir yang benar. Pemahaman konsep permutasi dan kombinasi yang bersifat terbuka, seringkali membuat mahasiswa melakukan kesalahan dalam menafsirkan soal. Setelah dilakukan tanya jawab, mahasiswa masih ragu untuk menentukan penyelesaiannya. Sebagian menjawab dengan melakukan kombinasi. Ada juga yang menjawab dengan permutasi, tetapi masih bingung dengan situasi yang ada dalam cerita tersebut,dimana ada kondisi yang menjadi prasyarat.

Selain itu, karakteristik materi permutasi dan kombinasi yang banyak memerlukan kemampuan penalaran, juga menyebabkan banyak mahasiswa mengalami kesulitan dalam menyelesaikan permasalahan tersebut. Oleh karena itu diperlukan suatu inovasi dalam pembelajaran yang dapat meningkatkan kemampuan tersebut.

Penelitian untuk mengatasi kesulitan dalam memahami permasalahan permutasi dan kombinasi sudah banyak dilakukan, antara lain penggunaan media cat air dengan pendekatan Matematika Realistik. Penelitian ini dilakukan di SMA Yos Sudarso Kepanjen oleh Mursidi (2013). Hasilnya menunjukkan bahwa siswa tidak melakukan kesalahan konseptual, prosedural dan kalkulasi setelah menerapkan pembelajaran ini.

Pengembangan

perangkat pembelajaran seperti LKS juga dilakukan dalam mengatasi kesulitan pemahaman materi peluang. Seperti pemelitian yang dilakukan oleh Mawarsari (2011) dan Dewi (2013). Kedua penelitian memberikan hasil bahwa penggunaan media seperti LKS dapat membantu menumbuhkan keaktifan siswa dalam memahami masalah permutasi dan kombinasi.

\section{Kesimpulan}

Berdasarkan hasil penelitian ini, dapat diambil kesimpulan bahwa kesulitan paling banyak yang dialami mahasiswa dalam membedakan permasalahan permutasi dan kombinasi adalah karena kurangnya kemampuan pemahamanterhadap masalah. Hal ini disebabkan kurangnya kemampuan penalaran dan logika yang dimiliki mahasiswa. 
Kemampuan dasar tentang permutasi dan kombinasi juga menyebabkan mahasiswa mengalami kesulitan dalam membedakan kapan penggunaan kedua metode ini. Karakteristik kedua metode ini yang hampir sama menjadi kendala bagi mahasiswa dalam mendapatkan hasil akhir yang benar.

\section{Ucapan Terima Kasih}

Terima kasih atas kerja sama yang baik kepada mahasiswa Program Studi Pendidikan Matematika FKIP UMB angkatan 2014 yang telah berkontribusi sehingga penelitian ini dapat terlaksana dengan baik.

\section{Pustaka}

Barbu, C Otilia. 2010. Effects of Linguistic Complexity and Math Difficulty on Word Problem Solving by English Learners. International Journal of Education, Vol. 2. No.2, E6, 1-19.

Clements, MA.1980. Analyzing Children's Errors on Written Mathematical Tasks. Educational Studies in Mathematics.

Clements, MA Ken \& Nerida F. Ellerton. 1998. Mathematics Education Research: Past, Present and Future. Mathematics Education Research Journal Volume 10 Issue 3, pp 7683, December 1998: Springer
Dahar, RW. 1988. Teori-teori Belajar. Jakarta: Erlangga.

Dewi, Devy Retnosari. 2013. Pengembangan Lembar Kerja Siswa untuk Pembelajaran Permutasi dan Kombinasi dengan Pendekatan Kontekstual untuk Siswa SMA Kelas XI. Artikel Ilmiah: Universitas Negeri Malang

Jamal, Fakhrul. 2014. Analisis Kesulitan Belajar Siswa dalam Mata Pelajaran Matematika pada Materi Peluang Kelas XI IPA SMA Muhammadiyah Meulaboh Johan Pahlawan. Jurnal MAJU (Jurnal Pendidikan Matematika, Vol 1 No 1 Maret 2014 hlm 18-36: STKIP Bina Bangsa Meulaboh.

Juanedi, Iwan. 2012. Tipe Kesalahan Mahasiswa dalam Menyelesaikan Soal-Soal Geometri Analitik Berdasar Newman's Error Analysis (NEA). (tersedia) [online] http://journal.unnes.ac.id Mawarsari, Venissa Dian. 2011. Pengembangan Perangkat

Pembelajaran Model Konstruktivistik untuk Mengoptimalkan Kemampuan Koneksi Matematik Peserta Didik Materi Peluang SMK Kelas XI. Artikel Ilmiah: Universitas Muhammadiyah Semarang. 
Mursidi, Veronika Ratna dan Gatot Muhsetyo. 2013. Penggunaan Media Cat Air dlam Memahamkan Materi Permutasi dan Kombinasi pada Siswa Kelas XI SMAK Yos Sudarso Kepanjen dengan Menggunakan Pendekatan Realistik. Artikel Ilmiah: Universitas Negeri Malang.

Mutakin, Tatan Zaenal. 2013. Analisis Kesulitan Belajar Kalkulus 1 Mahasiswa Teknik Informatika. Jurnal Formatif 3(1): 49-60 ISSN 2088-351X: Program Studi Pendidikan Matematika FTMIPA Universitas Indraprasta Jakarta.

Pratikipong,Natcha dan Satoshi Nakamura. 2006. Analysis of Mathematics Performance of Grade Five Students in Thailand Using Newman Procedure. Journal of International Cooperation in Education:CICE Hiroshima University.
Satoto, Seto, Hery Sutarto dan Emi Pujiastuti. 2013. Analisis Kesalahan Hasil Belajar Siswa dalam Menyelesaikan Soal dengan Prosedur Newman. Unnes Journal of Mathematics Education: Universitas Negeri Semarang

Shodiqin, Afiefah. 2011. Analisis Kesulitan Mahasiswa dalam Memahami Konsep Geometri Transformasi (Studi Kasus pada Mahasiswa Jurusan Pendidikan Matematika Semester VI Tahun Akademik 2010/2011 Institut Agama Islam Negeri Syekh Nurjati Cirebon). Skripsi Tidak Diterbitkan. IAIN Syekh Nurjati Cirebon.

White, Allan L. 2005. Active Mathematics in Calssrooms: Finding Out Why Children Make Mistakes - And Then Doing Something to Help Them. Square One, Vol 15 No 4, December 2005: University of Western Sydney. 